\title{
Universitetsundervisning i det 21. århundrede: Læring, dannelse, marked
}

\author{
Anmeldelse af Bettina Dahl Søndergaard, lektor, CSE (ST), Aarhus Universitet. \\ Jakob Egholm Feldt og Nina Bonderup Dohn (red.): \\ Universitetsundervisning i det 21. århundrede: Læring, dannelse, marked. \\ Syddansk Universitetsforlag, 2011. \\ 186 sider.
}

Bogen er en antologi, der er bygget op med et indledende og afrundende kapitel af redaktørerne, og derimellem er der seks kapitler skrevet af forskellige forfattere. Flere af de enkelte kapitler henviser til andre kapitler i bogen, hvilket giver indtryk af en gennemarbejdet og sammenhængende bog. Det indledende kapitel, skrevet af de to redaktører, "sætter scenen" og beskriver formålet med antologien som følger:

"Bogens mål er ikke en samlet præsentation af universitetspædagogisk filosofi, men en diskussion mellem læringsforskere og engagerede praktikere om universitetets undervisning. Vi sætter fokus på, at læringsforskere og praktikerne er del af samme overordnede human-samfundsvidenskabelige felt og derfor kan føre en bred og alligevel fagligt relevant debat om, hvad universitetets undervisning er og bør være." (s. $8)$.

Anmelderen er helt enig i, at det er et stadig relevant formål at diskutere, hvad universitetets undervisning er $i$ et moderne samfund i stadig udvikling, og hvordan vi kan navigere mellem forskellige hensyn.

Helt bevidst er der ikke bidrag fra naturvidenskab, idet:

\begin{abstract}
"Samtidig er det i hoj grad inden for human- og samfundsvidenskaberne, at universitetets mening og mål artikuleres, og her universitetets pædagogiske filosofiske strategier udvikles, så derfor har antologiens problemstillinger alligevel en almen interesse for universitetsundervisere, studerende og andre interesserede $i$ universitetets situation $i$ samfundet og fremtiden." (s. 7).
\end{abstract}

\begin{abstract}
Anmelderen har imidlertid en naturvidenskabelig baggrund (hovedfag i matematik og lektor i matematikdidaktik på Aarhus Universitets hovedområde Science and Technology) og blev her en anelse provokeret. Hvad menes der med, at det særligt er hos de andre hovedområder, at universitetets mål og mening artikuleres? Af egen
\end{abstract}


erfaring ved jeg, at disse ting også livligt diskuteres af folk på naturvidenskab. Dog er det givetvis rigtigt, at måden, det diskuteres på her, er anderledes, bl.a. i forhold til den litteratur man henviser til, men jeg vil mene, at det netop derfor ville have været en styrke ved bogen, om man havde inkluderet forfattere fra flere fakulteter. Bogen ville så måske have fremstået mindre homogen end den faktisk gør. Som den er nu, er der som nævnt ovenfor krydshenvisninger, og kapitlerne "taler sammen". Men jeg vil alligevel argumentere for, at en bog hvis formål er at diskutere formålet med hele universitetets undervisning, bør have bidragydere fra hele universitetet. Alternativt kunne en underoverskrift have været: "Set i human- og samfundsvidenskabeligt perspektiv". Dog har skribenterne til indledningens side 7, citeret foroven, også ret i, at de ting, der beskrives i bogen, har almen interesse og også for det meste er skrevet, så folk uden for human- og samfundsvidenskaberne vil få noget ud af at læse det.

I indledningen gives bl.a. en overordnet teoretisk ramme, hvori man kan indlæse de næste seks kapitler. Denne ramme er de såkaldte "modus 1-3-" perspektiver på læring og forskning. Med modus 1 sigtes der på fortalerne for det moderne humboldtske universitet med klassiske universitetsdyder som fri forskning, uafhængighed af staten, og hvor den sande viden er målet. Modus 2-perspektivet er kritisk over for modus 1 af forskellige årsager men har stort fokus på praksisfællesskaber og på, hvordan viden skabes i forskellige kontekster. Det er en smule uklart på dette sted, hvad der egentlig ligger i modus 2, men det bliver klarere i nogle af de mellemliggende kapitler. Essentielt for modus 3 er den eksistentielle dimension i et praksisfelt. Altså at man for at kunne udøve sin praksis optimalt skal være dannet og være sig selv i den praksis således, at man:

"... intuitivt kan føle og mærke sagen, hoad den betyder, og hoad man skal gøre. Med modus 3 lægges der således vægt på, at der til nytænkning hører betydningsfulde eksistentielle og ontologiske forhold, som skal medtrnkes i den universitetspædagogiske praksis, hvis ikke vi vil gøre skade på åndens liv." (s. 10).

Det er meget prisværdigt, at man i indledningen giver dette begrebsapparat for bedre at kunne forstå de mellemliggende kapitler. Det er vitterligt en hjælp for læseren, og det er også med til at give et indtryk af en bog, der er helstøbt. Mit indtryk er dog, at eksempelvis modus 3-tankegangen på sin vis ikke er hverken fremmed eller ny i forhold til eksempelvis matematik. Det er ikke usædvanligt, at en matematiker beskriver vigtigheden af, at de studerende har en matematisk "sans", kan forstå matematikkens "sjæl", eller at man som matematiker kan "føle", om man er på rette spor i et bevis eller problemløsning. Meget af denne (ubevidste) del af matematikkens psykologi blev rent faktisk allerede beskrevet i 1945 af Hadamard i bogen An Essay on The Psychology of Invention in the Mathematical Field. Desuden er et af formålene med 
den såkaldte KOM-rapport (Niss et al., 2002) at lave en samlet fremstilling af de matematiske kompetencer, elever og studerende skal udvikle gennem hele skole- og universitetetsforløbet. Denne rapport diskuterer også det såkaldte begrundelsesproblem for matematikken. Altså, hvorfor skal vi undervise i matematik, og hvilken matematik skal det i givet fald være? Rapporten nævner (Niss et al., 2002, s. 151-151) eksempelvis den økonomisk-teknologiske årsag, den individorienterede årsag og den politisk-kulturelle årsag. Disse diskuteres indgående med reference til både dansk og international litteratur.

Disse matematikeksempler har til formål at illustrere, at der også uden for de human-samfundsvidenskabelige områder er megen metarefleksion over formålet med universitetsundervisningen - eksempelvis matematikundervisningen. Der bruges et andet begrebsapparat, men det er ikke længere fra hinanden, end at paralleller tydeligt kan ses, og forstås. Og så bliver det jo virkelig interessant!

De mellemliggende seks kapitler er spændende læsning. Det er trods alt seks forskellige perspektiver på bogens temaer, selvom der dog er fravær af rene fortalere/forsvarere af universitetets nuværende situation med taxametertilskud, læringsmål og fokus på gennemførelse. Jeg vil ikke give et fyldigt referat af hver af disse for ikke at røbe for meget, men dog alligevel kort beskrive nogle af deres fokusområder og knytte enkelte kommentarer til dem.

Kapitlet "Universitetets overordnede mål bør være at skabe frihed for 'åndens liv'" af Finn Thorbjørn Hansen er et eksempel på modus 3-betragtninger. Nogle af FTH's begreber er meget teoretiske, men der kommer senere et eksempel med en sygeplejestuderende, der "kunne" sit stof, men hvor faget "aldrig helt blev en del af hende selv - som om at det, hun læste, udelukkende blev siddende i hovedet og aldrig rigtig kom til udtryk igennem hendes måde at agere og være på i afdelingen og over for patienterne." (s. 26). Dette leder til en rigtig interessant diskussion af, om dette er vigtigt eller ej. Desuden tager FTH også spørgsmålet op om, "Hvad vil det sige at lære i forhold til en ukendt fremtid?" (s. 39).

I kapitlet "Jeg har fået mulighed for at være lost - om at give mulighed for læring" skriver Lene Tanggaard, at der er noget af det, der læres på universitetet, som er umuligt at eksplicitere sprogligt, og at kompetencemål i undervisningen derfor kun er den halve sandhed. LT beskriver læring som kulturtilegnelse, og at det nogle gange er vigtigt at få lov til at være fortabt og ikke vide, hvad næste skridt er. LT beskriver også, at det i dag mere end nogensinde er vigtigt at "beskrive de mesterlærelignende læringsmiljøer, der rent faktisk findes på universiteterne, fordi de risikerer at forsvinde, når og hvis undervisning i alt for høj grad uddelegeres til undervisere, der ikke selv er skabende forskere." (s. 57). 
I kapitlet "Den skønne undervisning: Universitetets undervisning set som videnskabelig dannelse" af Jakob Egholm Feldt skriver han, at han opfatter konflikten mellem forskellige tanker om universitetsundervisningen som bl.a. en konflikt mellem universitetets sprog og forpligtelserne over for underviserne. Eksempelvis forandrede incitamentsstrukturer og læringsteknologi og markedsorienteret kundepleje universitetet. Han skriver f.eks.: "Universitetet er simpelthen ikke universitet, hvis undervisningen bliver pædagogisk med henblik på de studerendes læring og gennemførelsesprocent." (s. 72). JEF inddrager her bl.a. Humboldt og diskuterer vigtigheden af, at studerende får mulighed for at opleve og erfare den livsform, det er at være studerende og lade denne forandre dem. Det bliver en interessant og vigtig diskussion, men anmelderen mener dog personligt, at undervisere altid har pligt til at tilrettelægge undervisningen "pædagogisk", så man ud fra viden om hvordan studerende lærer overvejer, hvilke dele af et kursus kan undervises som hhv. forelæsning, øvelser eller andet. Anmelderen vil stille det retoriske spørgsmål: Er det en dyd at være upædagogisk?

Kapitlet "Nul-risiko universitetet: fra Bildung til interkulturelle kompetencer" er skrevet af Maribel Blasco, som skriver: "Det er min teori, at neoliberale tendenser præger læringen på nutidens højere læreanstalter på forskellige måder." (s. 96). F.eks. et "fokusskifte fra læringsinput- og proces mod læringsoutput, især i form af præstérbare resultater" (s. 102), som MB ser som et skridt hen imod et behavioristisk syn på læring. Diskussionen er interessant og kommer omkring flere andre områder, men anmelderen mener, at skelnen mellem læringsinput/proces og -output er for kategorisk. Eksempelvis beskriver kvalifikationsrammen for kandidatniveau, at kandidaten bl.a. skal opnå den kompetence "selvstændigt at kunne tage ansvar for egen faglig udvikling og specialisering", ergo et fokus på læringsprocessen. Anmelderen er dog helt på linie med $\mathrm{MB}$, når denne skriver, at det er "vanskeligt at bygge udvikling ind i uddannelserne, når så få kursuselementer er obligatoriske." (s. 104).

Kapitlet "Universitetsædagogikkens dilemmaer" af Søren Harnow Klausen diskuterer det klassiske ideal om enhed mellem forskning og undervisning, og hvordan dette udfordres af et moderne universitet, hvor de færreste studerende sigter mod en forskerkarriere. SHK skriver også særligt om differentiering af undervisningen, og hvilke negative effekter denne har men også: "Løsningen består i en stadig afstemning af de forskellige interesser og behov ... så megen imødekommenhed over for de studerendes interesser som er mulig, når de samtidig skal lære andre ting, og den faglige tradition skal vedligeholdes." (s. 128).

Kapitlet "På vej mod det ukendte: Motivation, undring og identitet i universitetetsundervisningen" af Liv Egholm Feldt fokuserer bl.a. på det generelle læringsspørgsmål om, hvordan man kan erkende noget, man endnu ikke kender til, hvad 
der er god og dårlig universitetsundervisning, og hvad forandringer i universitetets samfundsmæssige rolle betyder for, hvordan man tænker om universitetet. Her inddrager LEF i særlig grad Peirce og begrebet abduktion.

Det afrundende kapitel skrevet af den ene redaktør, Nina Dohn, indeholder metabetragtninger om forskellige dikotomier, som berøres i de seks kapitler, eksempelvis mellem kompetence og dannelse - og mellem sagens udvikling og den lærendes læring. Kapitlet slutter af med "Et tentativt bud bag om dikotomierne". Dette er en diskussion, som i høj grad hæver sig over de enkelte kapitler og viser en vej fremad. Anmelderen er personligt meget enig i NDs betragtninger i det afsluttende kapitel om, at nogle af de dikotomier, der kan sættes op, ikke er ægte dikotomier. For eksempel at det at have læringsmål skulle være i modstrid med dybde og nysgerrighed. ND skriver: "Men spørgsmålet er, om noget tilsvarende ville gælde, hvis læringsmålene var af mere almen karakter ... "kritisk stillingtagen" ... I sådanne tilfælde synes en entydig kombling mellem didaktik og instrumentel mål-middeltænkning for snæver." (s. 162).

Som eksempel vil anmelderen henføre til Aarhus Universitets naturvidenskabelige område, som i 2007 i forbindelse med den nye karakterskala besluttede, at alle kursusbeskrivelser skulle tilføjes læringsmål skrevet ud fra Biggs' SOLO-taksonomi (Biggs, 2003; Brabrand \& Dahl, 2009). SOLO-taksonomien består af fem niveauer, hvoraf det sidste niveau "Extended abstract" handler om kompetencer, der rækker ud over det givne, for eksempel at en studerende kan generalisere, kan se en struktur fra flere perspektiver og overføre teorier til nye områder. Eksempler på sådanne kompetencer (verber) er: diskutere, evaluere, kritisere, fortolke, forudsige, perspektivere, ræsonnere, generalisere, estimere osv. Er selvstændighed et mål, kan dette også formuleres ind i læringsmålene for et kursus. Der er altså ikke lighedstegn mellem en tænkning i læringsmål og et fravær af kritiske kompetencer.

Sluttelig har anmelderen lyst til at inddrage noget litteratur om emnet, som ingen af de ovennævnte forfattere henviser til. I bogen The Saber-Tooth Curriculum (2004 [1939]) beskriver forfatteren Peddiwell et fiktivt folkeslag i gammel tid, fjernt fra Danmark, som bl.a. lever af de fisk, de fanger, og de overlever ved at være i stand til jage de farlige sabeltigre væk med ild. Samfundet opretter på et tidspunkt et skolesystem, hvor man undervise de unge i de bedste metoder til f.eks. at jage disse tigre væk med ild. På et tidspunkt sker der så mange omskiftninger i deres levevis, at disse metoder ikke længere er aktuelle - der er f.eks. ikke flere sabeltigre at skræmme væk. Spørgsmålet, der opstår, er dernæst, om skolen af dannelsesmæssige og historiske grunde skal vedblive med at undervise $i$, hvordan man skræmmer disse sabeltigre. Det er en uhyre interessant diskussion, der skildres, mellem forskellige dele af samfundet, så jeg kan varmt anbefale bogen, men det er også spørgsmål, vi kan stille 
os i dagens Danmark på et moderne universitet (og andre steder i uddannelsessystemet). Det kan somme tider være godt at se tingene lidt udefra - og måske stille spørgsmålet, om vi har elementer af The Saber-Tooth Curriculum på universitetet - og i givet fald, om det gør noget? Som Nina Dohn skriver i sit afsluttende kapitel, så er mange dikotomier ikke ægte dikotomier. Heller ikke denne. Det er ikke et spørgsmål om enten-eller, men om både-og. Som Finn Thorbjørn Hansen bl.a. citerer Hammershøj for, er universitetet bærer af en tradition (s. 30), men et universitet er omvendt heller ikke et museum. Det er et sted for vidensproduktion og uddannelse til et moderne samfund. Som det skrives af FTH, skal vi uddanne unge til en fremtid, vi ikke kender, hvorfor nogle generelle (og klassiske) kompetencer er uhyre vigtige, men fagene i sig selv er, og har altid været, under stadig udvikling. Diskussionen er i stedet, hvor meget af hvad - og hvornår - og, ikke mindst, hvordan skal der så undervises i dette. Bogen er her et interessant indspark i diskussionen om målet med universitetsundervisningen i det 21. århundrede.

Som læseren af denne anmeldelse måske kan fornemme, mener jeg at bogen giver anledning til nogle gode diskussioner om formålet med universitetsundervisningen i dag. Den rekapitulerer og giver en opsummering af de klassiske tanker og diskussioner om dannelse og det humboldtske universitet. Dette er der som sådant ikke noget nyt i, og man kan læse disse ting andre steder, men det nye er, at man kommer ud over dette. Dette sker bl.a. ved diverse krydshenvisninger i bogen men mest af alt, fordi bogens kapitler er indrammet af en god indledning og afslutning, der sætter kapitlerne i perspektiv og rækker fremad. Jeg vil derfor meget gerne anbefale bogen til alle med interesse for spørgsmålet om formålet med universitetets undervisning $\mathrm{i}$ dag.

\section{Litteratur}

Biggs, J. B. (2003). Teaching for Quality Learning at University. Maidenhead: Open University Press.

Brabrand, C. \& Dahl (Søndergaard), B. (2009). Using the SOLO-taxonomy to analyze competence progression of university science curricula. Higher Education, 58(4), 531-549.

Hadamard, J. (1945). An Essay on The Psychology of Invention in the Mathematical Field. New York, Dover.

Niss, M. et al. (2002). Kompetencer Og Matematiklæring [KOM-rapporten]. København: Undervisningsministeriet.

Peddiwell, J. A. (2004 [1939]). The Saber-Tooth Curriculum. New York: McGraw-Hill. 